\title{
Analysis of Consumer Behavior in the Use of Online Shop with the Fuzzy Logic Tahani Method in Manado City Indonesia
}

\author{
Marike A. S. Kondoj \\ Department of Electrical \\ Engineering \\ Manado State Polytechnic \\ Manado, Indonesia
}

\author{
Daisy Sundah \\ Department of Business \\ Administration \\ Manado State Polytechnic \\ Manado Indonesia
}

\author{
Sukandar Sawidin \\ Department of Electrical \\ Engineering \\ Manado State Polytechnic \\ Manado, Indonesia
}

\begin{abstract}
This study aims to obtain information about online shopping models that are in demand by the public, especially those in the city of Manado. Analysis of consumer behavior becomes very important in efforts to develop an e-commerce model application for coconut-derived products. An effective and efficient e-commerce model can be developed for buyers and sellers. Referring to the Likert scale, the information obtained is analyzed using the Fuzzy Tahani method so that it can provide results that become a reference for the development of e-commerce services for coconut-derived products that can be developed for information technology-based smart services.
\end{abstract}

\section{Keywords}

e-commerce, fuzzy tahani, model..

\section{INTRODUCTION}

Fundamental changes that also influence consumer behavior are triggered by the development of information technology that is growing rapidly entering the 21 st century. The development of the internet in the last decade has brought radical changes to the world of trading in various types of commodities [1]. The needs of urban communities with a high level of busyness is one of the factors that drive the need for fast and practical services.

Online shopping is a process in which consumers can directly buy goods or services from the seller in realtime, via the Internet. The emergence of new shopping channels, namely through internet media, has led many companies to start their stores online. Today many online stores are present and provide attractive services to consumers so that they get a substantial profit because with a small capital the seller can have a shop / place to sell with only a sales website. Ease of Use. According to [2]. Consumer behavior is the study of how individuals, groups and organizations choose, buy, use and place goods, services, ideas or experiences to satisfy their wants and needs. Consumer behavior is an integral part of a decision to choose what you want to do with the expected goals, consumer behavior describes the way individuals make decisions to utilize their available resources (time, money, effort) to buy goods related to consumption[3].

Evaluation of business intelligence for a company system before buying and implementing it is very important the importance of creating a decision support environment for managers in organizations including the decision to develop a sales system that suits market needs. There are some delimited efforts to evaluate business intelligence, but always they consider business intelligence as tools or separated systems to enterprise systems. Designed business intelligence performance model to measure business intelligence[4]. To this aim, the measurement and the evaluation in bisnis intelegensi filed was restricted to prove business intelligence investment worth and business intelligence values. Elbashir, Collier, and Davern (2008) have discussed about measuring the effects of business intelligence systems on business process, and have presented model for effect measures[5]. Also Lin, Tsai, Shiang, Kuo, and Tsai (2009) have developed performance assessment model for business intelligence systems using ANP, but they have considered business intelligence as separated systems again[6].

\section{LITERATURE REVIEW}

Fuzzy logic is one method that can be used to describe a process that is mapping input into the output space. This technique uses a mathematical theory of fuzzy sets. Fuzzy logic is related to uncertainty that has become human nature. The basic idea of fuzzy logic comes from the principle of obscurity. Fuzzy theory was first built by embracing the principle of set theory. In conventional sets (crisp), elements of the universe are members or not members of set. Thus, membership of the set is fixed (Kusumadewi, 2002).

Fuzzy in language can be interpreted faintly, in other words fuzzy logic is a vague logic. In fuzzy logic a value can be 'true' and 'false' simultaneously. The level of 'true' or 'false' value in fuzzy logic depends on the weight of the membership it has. Fuzzy logic has membership degrees ranging from 0 to 1 , in contrast to digital logic which only has two 0 or 1 membership at a time [7].

Behavior is the study of how individuals, groups and organizations choose, buy, use and place goods, services, ideas or experiences to satisfy their wants and needs ".

According to Schiffman and Kanuk (2008: 6), "consumer behavior describes the way individuals make decisions to utilize their available resources (time, money, effort) to buy goods related to consumption". consumer behavior is related to the desire to do something that can give satisfaction and as desired.

\section{RESEARCH METHOD}

Fuzzy Tahani is a fuzzy method that uses a standard database. In a standard database, data is classified based on how the data is viewed by the user. Therefore in the standard database the data displayed will come out as the data that has been stored. Fuzzy database model Tahani still uses a standard relation, but the Tahani model uses fuzzy set theory on a variable to obtain information in its query. So that in the search for data using the formula of the degree of membership 
in a fuzzy set variable [8]. The following are the fuzzy logic stages of the Tahani model [9], namely first describing the membership function for each criterion or fuzzy variable, which is a curve that shows the mapping of data input points into its membership value (membership degree) which has an interval between 0 to 1 , one of the ways that can be used is a function approach. Approach to a triangular membership function. The second phase of Fuzzification is the first phase of the fuzzy calculation, which is the conversion of strict values to fuzzy values. Where each fuzzy variable is calculated the value of the degree of membership to each fuzzy set. The last step is Query Fuzzification as a query for a conventional DBMS that creates and implements a fuzzyquery logic system with a basic relation.

\section{DISCUSSION RESULT}

To design an e-commerce model, data collection is one of the important stages in system development. Data collection is needed to get detailed information about the model to be developed [10]. In collecting data, techniques data collection used in this study are: observation, interview and questionnaire.

Refers to a management philosophy, business intelligence is a tool that helps organizations to manage and refine business information to make effective decisions [11]. Conditions that are possible to support the concept of thought above :

1 Information and knowledge are important in terms of organization, business and how market conditions, customers and competitors and economic problems occur [12-13];

2 A structured and systematic process for analyzing to support business decisions [12-13].

Based on the description above, the data obtained is processed to be used as an analytical tool that provides information on decision making to develop e-commerce.

Consumer motivation becomes one of the determinants of business development. E-commerce business provides opportunities for consumers to carry out shopping mechanisms through the web and provides opportunities for companies to create and expand a business environment that is rich cognitively and aesthetically in a way that is unique and not easily replicated in the conventional shopping [15].

From the results of the questionnaire, data is obtained as shown in the table below:

Table 1. Responden

\begin{tabular}{|c|c|c|}
\hline Icome & Online & Offline \\
\hline $1.500 .000-3.500 .000$ & 8 & 17 \\
\hline $3.500 .000-5.500 .000$ & 16 & 9 \\
\hline 5.500 .000 and above & 15 & 10 \\
\hline Age & & \\
\hline $17-25$ years & 22 & 3 \\
\hline $26-40$ years & 18 & 7 \\
\hline 40 years and above & 15 & 10 \\
\hline
\end{tabular}

Based on the table above, get the degree of membership of each variable :
1. Variable Income

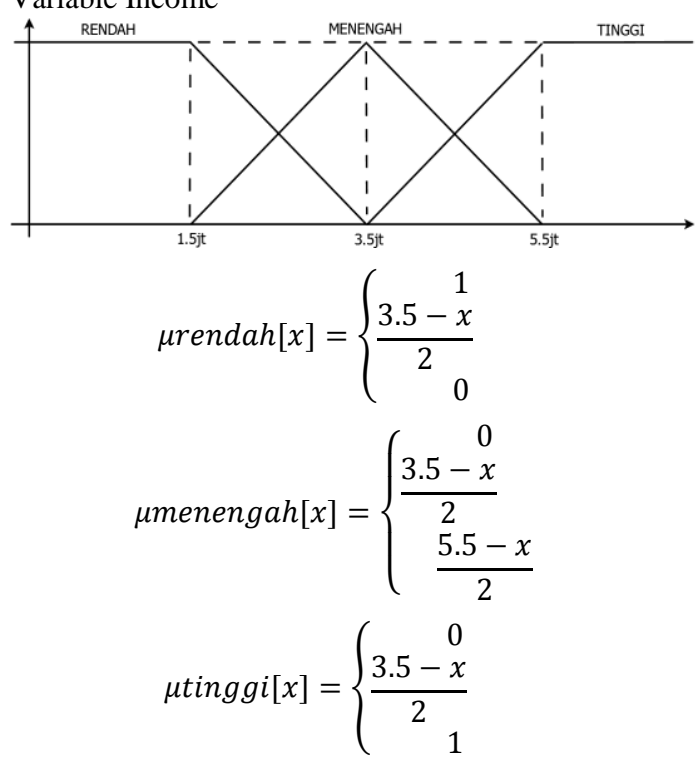

2. Variable Age

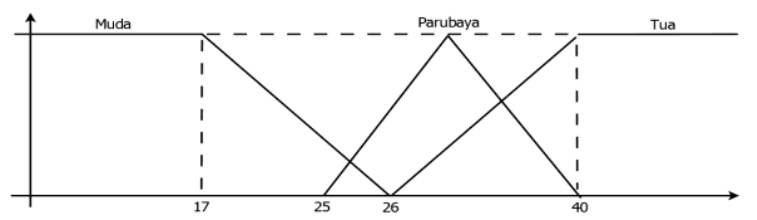

$$
\begin{aligned}
& \operatorname{muda}[x]=\left\{\begin{array}{c}
1 \\
\frac{26-x}{26-25} \\
0
\end{array}\right. \\
& \text { uparubaya }[x]=\left\{\begin{array}{c}
\frac{x-25}{26-25}-25 \\
\frac{40-x}{40-26}
\end{array}\right. \\
& \text { uparubaya }[x]=\left\{\begin{array}{c}
0 \\
\frac{x-26}{14}-25 \\
1
\end{array}\right.
\end{aligned}
$$

Fuzzy logic as a methodology for managing uncertainty in rule-based structures. In fuzzy logic inference systems, more rules can shoot at a certain time than in a sharp expert system[14].

In determining membership functions there are several steps taken by the system to convert raw car data into input data fuzzy (fuzzification process).

Variable Income : Low, middle and High

Variabke Age : young, middle-aged and old.

Table 2. Rules

\begin{tabular}{|c|c|c|}
\hline Icome & Age & Result \\
\hline low & old & F \\
\hline low & young & F \\
\hline low & middle-aged & F \\
\hline middle & middle-aged & F \\
\hline high & young & T \\
\hline middle & old & F \\
\hline
\end{tabular}




\begin{tabular}{|c|c|c|}
\hline high & middle-aged & $\mathrm{T}$ \\
\hline high & old & $\mathrm{T}$ \\
\hline middle & young & $\mathrm{F}$ \\
\hline
\end{tabular}

Consumer behavior in online shopping by utilizing internet media to make transactions. There are several processes in the online shopping process that are often done by consumers to find the needs of goods or services by searching for information via the internet. In certain conditions sometimes consumers are more interested in looking for some information then comparing the information obtained to get satisfaction with online shopping. It can be interpreted that consumer psychology greatly influences decisions in online shopping. [16]. Situations and conditions affect decisionmaking strategies. With perceived shopping convenience and attractive offers will affect consumers to do electronic shopping, because it does not take up much work time. Having unlimited access to a number of online stores makes online shopping very enjoyable. However, it must be realized that consumers have limited cognitive resources and needed solutions or tools that can help consumers to digest every information obtained so that they can manage and utilize wisely in electronic shopping [17]. Consumer motivation is one of the factors that are key in doing online shopping. It is this motivation that encourages consumers to choose ways to shop according to their wants and needs. [18].

The results obtained show that age and economic factors influence consumer decisions in purchasing products or goods electronically. In certain conditions online shopping is not the main choice for consumers to get the desired item. This is due to some consumers not being able to make transactions and worry if the items or products ordered do not match the information obtained.

\section{CONCLUSION}

Consumer behavior analysis is used as the basis for building e-commerce systems for coconut derivatives. The results show that consumer behavior in Manado is quite good at using online shop. There are mixed findings on the relationship between age and online shopping intention and Income is positively related to online shopping tendency.

\section{ACKNOWLEDGMENTS}

Thank you for all who took part in this research and the Ministry of Research and Technology who have supported the financing of this research activity.

\section{REFERENCES}

[1] Han, J. W., Zheng, H. F., Cui, Y., Sun, L. D., Ye, D. Q., Hu, Z., ... \& Xie, H. F. (2009). Genome-wide association study in a Chinese Han population identifies nine new susceptibility loci for systemic lupus erythematosus. Nature genetics, 41(11), 1234.

[2] Fatharani, A., Lubis, N., \& Dewi, R. S. (2013). Pengaruh Gaya Hidup (Life Style), Harga (Price), dan Kelompok Referensi (Reference Group) terhadap Keputusan Pembelian Telepon Seluler Blackberry (Studi Pada Mahasiswa Program S1 Angkatan 2009 Fakultas Ilmu Sosial dan Ilmu Politik Universitas Diponegoro). Jurnal Ilmu Administrasi Bisnis, 2(3), 57-76.

[3] Schiffman, Leon G dan Leslie Lazar Kunuk. 2008. Perilaku Konsumen. PT. Indeks. Jakarta.
[4] Pirttimäki, V., Lönnqvist, A., \& Karjaluoto, A. (2006). Measurement of business intelligence in a Finnish telecommunications company. The Electronic Journal of Knowledge Management, 4(1), 83-90.

[5] Elbashir, M. Z., Collier, P. A., \& Davern, M. J. (2008). Measuring the effects of business intelligence systems: The relationship between business process and organizational performance. International Journal of Accounting Information Systems, 9(3), 135-153.

[6] Lin, Y. H., Tsai, K. M., Shiang, W. J., Kuo, T. C., \& Tsai, C. H. (2009). Research on using ANP to establish a performance assessment model for business intelligence systems. Expert Systems with Applications, 36(2), 41354146.

[7] Taufiq, G. (2014). Logika Fuzzy Tahani Untuk Pendukung Keputusan Perekrutan Karyawan Tetap. In Prosiding Seminar Nasional Aplikasi Sains \& Teknologi (SNAST) (pp. 99-106).

[8] Kusumadewi, Sri. Purnomo, Hari. 2010. Aplikasi Logika Fuzzy untuk Pendukung Keputusan. Edisi . Kedua. Cetakan Pertama. Yogyakarta: Graha Ilmu.

[9] Kahar, N. 2013. Sistem Pendukung Keputusan Penerima Jamkesda Di Kota Jambi. Konferensi Nasional Informatika. Vol 1, pp, 215-220.

[10] Saroinsong, T., Kondoj, M. A., Kandiyoh, G., \& Pontoh, G. (2018, January). Design and Implementation of Integrated Software Research and Community Service at State Polytechnic of Manado. In Journal of Physics: Conference Series (Vol. 953, No. 1, p. 012037). IOP Publishing.

[11] Gbosbal, S., \& Kim, S. K. (1986). Building effective intelligence systems for competitive advantage. Sloan Management Review (1986-1998), 28(1), 49.

[12] Lönnqvist, A., \& Pirttimäki, V. (2006). The measurement of business intelligence. Information systems management, 23(1), 32.

[13] Rouhani, S., Ghazanfari, M., \& Jafari, M. (2012). Evaluation model of business intelligence for enterprise systems using fuzzy TOPSIS. Expert Systems with Applications, 39(3), 3764-3771

[14] Keller, J. M., Yager, R. R., \& Tahani, H. (1992). Neural network implementation of fuzzy logic. Fuzzy sets and systems, 45(1), 1-12.

[15] Childers, T. L., Carr, C. L., Peck, J., \& Carson, S. (2001). Hedonic and utilitarian motivations for online retail shopping behavior. Journal of retailing, 77(4), 511535 .

[16] Li, N., \& Zhang, P. (2002). Consumer online shopping attitudes and behavior: An assessment of research. AMCIS 2002 Proceedings, 74.

[17] Häubl, G., \& Trifts, V. (2000). Consumer decision making in online shopping environments: The effects of interactive decision aids. Marketing science, 19(1), 4-21.

[18] Zhou, L., Dai, L., \& Zhang, D. (2007). Online shopping acceptance model-A critical survey of consumer factors in online shopping. Journal of Electronic commerce research, 8(1). 